\title{
Origins of magic: review of genetic and epigenetic effects
}

\author{
Sreeram V Ramagopalan, ${ }^{12}$ Marian Knight, ${ }^{3}$ George C Ebers, ${ }^{12}$ Julian C Knight ${ }^{1}$
}

\begin{abstract}
${ }^{1}$ Wellcome Trust Centre for Human Genetics, University of Oxford, Oxford OX37BN

${ }^{2}$ Department of Clinical Neurology, University of Oxford

${ }^{3}$ National Perinatal Epidemiology Unit, University of Oxford

Correspondence to: J C Knight

julian@well.ox.ac.uk
\end{abstract}

BMJ 2007;335:1299-301 doi:10.1136/bmj.39414.582639.BE Accepted: 16 November 2007

\section{ABSTRACT}

Objective To assess the evidence for a genetic basis to magic.

\section{Design Literature review.}

Setting Harry Potter novels of J K Rowling.

Participants Muggles, witches, wizards, and squibs. Interventions Limited.

Main outcome measures Family and twin studies, magical ability, and specific magical skills.

Results Magic shows strong evidence of heritability, with familial aggregation and concordance in twins. Evidence suggests magical ability to be a quantitative trait. Specific magical skills, notably being able to speak to snakes, predict the future, and change hair colour, all seem heritable.

Conclusions A multilocus model with a dominant gene for magic might exist, controlled epistatically by one or more loci, possibly recessive in nature. Magical enhancers regulating gene expression may be involved, combined with mutations at specific genes implicated in speech and hair colour such as FOXP2 and MCR1.

\section{INTRODUCTION}

Genetic factors that underlie traits such as height ${ }^{1}$ and weight ${ }^{2}$ are currently under scrutiny using genome wide association methods, yet the detection of genes predisposing to magic has been given relatively short shrift. Using the books by J K Rowling about Harry Potter, a schoolboy wizard, to gain an insight into humans with magical abilities, one study suggested that magic is the result of a single gene. ${ }^{3}$ This assertion has been contentious, however, with another study questioning whether magic is heritable. ${ }^{4}$ We assessed the heritability of magic now that the Harry Potter series is complete with the publication of the seventh and final book. ${ }^{5}$

According to the Harry Potter books ${ }^{5-11}$ most people in the world are muggles-that is, possess no magical ability-whereas a minority are witches and wizards with magical abilities. Rarely we are introduced to squibs, offspring resulting from the non-transmission of magic within a family with magical abilities. Compared with muggles squibs have some magical ability, as they can see and interact with the magical world.

When considering the genetics of magic we need to be able to explain several observations. Firstly, matings between humans with magical abilities produce offspring with magical abilities, rarely squibs, and not muggles. Secondly, matings between humans with magical abilities and muggles seem to always produce offspring with magical abilities. Thirdly, matings between muggles produce either muggles or, rarely, offspring with magical abilities and never squibs. Finally, parent of origin effects are not apparent-examples exist of wizards with muggle father and wizard mother parentage and vice versa.

\section{METHODS AND RESULTS}

We used the Harry Potter novels by J K Rowling ${ }^{5-11}$ as original source material to identify characters from the magical and non-magical world-namely, muggles, witches, wizards, and squibs (see glossary)-their magical abilities, and familial relationships. To avoid factual errors, different members of the team carried out repeated readings of the novels and listened to unabridged audio productions of the books.

\section{Magical family lineages}

Firstly, we estimated familial aggregation to detect whether a characteristic has a genetic component. ${ }^{12}$ The final Harry Potter book Harry Potter and the Deathly Hallows ${ }^{5}$ goes into great detail about magical families, notable examples being the Black and Gaunt lineages. Only one example of the non-transmission of magic is described, resulting in a squib offspring. Although shared environmental influences can also lead to familial clustering of a trait, the presence of magical abilities in seven generations of the Black family and at least three generations in others strongly suggests the influence of genetic factors in determining magical ability. This might also be true for non-human magical creatures-for example, the house elf Kreacher and his ancestors who have served the Black family for generations.

\section{Twin studies}

Although assumptions are made, complete genetic determination of a disease would result in monozygotic twins being concordant. ${ }^{12}$ The two pairs of twins in the Harry Potter books, the Patil and Weasley twins, are monozygotic and both have magical abilities. Although two sets of twins is a small sample size, 
the finding does add credence to the idea of magic being a genetically determined trait.

\section{Quantitative traits}

Magic is not a dichotomous trait; we prefer the idea of magical ability, a quantitative attribute, ranging from the talents of Albus Dumbledore, Harry's headmaster at Hogwarts School of Witchcraft and Wizardry, to the relative ineptitude of Crabbe and Goyle, the sidekicks of Harry's nemesis Draco Malfoy. Magical ability also seems to be genetically determined, with familial aggregation highlighted by the Weasley twins who seem equally matched in aptitude, and the magical abilities of Harry Potter. Harry was raised by muggles after the death of his magical parents, James and Lily Potter, before his first birthday; although James and Lily were outstanding wizards, exemplified by their role as head boy and head girl at Hogwarts school, the environment of 4 Privet Drive where Harry lived with his muggle relatives, the Dursley family, could not have been further removed from the magical world. This situation would be similar to an adoption study, the most powerful way of disentangling genetic influences from those of the environment. ${ }^{12}$ Variation in a quantitative trait usually results from the contributions of multiple genes, with small effects modified by environmental influences. ${ }^{13}$ Magical ability is likely to be affected by the environment, with experience and emotional state being important factors.

\section{Single gene effects}

In the spectrum of magical ability three skills seem likely to be conferred by specific genes. One of these skills is speaking to snakes (parseltongue), known to be a feature of only direct descendants of Salazar Slytherin, one of the four founders of Hogwarts school. Another skill is clairvoyance. Sybill Trelawney, a professor of divination at Hogwarts school, is a seer and so was her great great grandmother. Lastly, Nymphadora Tonks, a character in the fifth Harry Potter book The Order of the Phoenix, was able to change her physical appearance (a metamorphmagus) and so was her son.

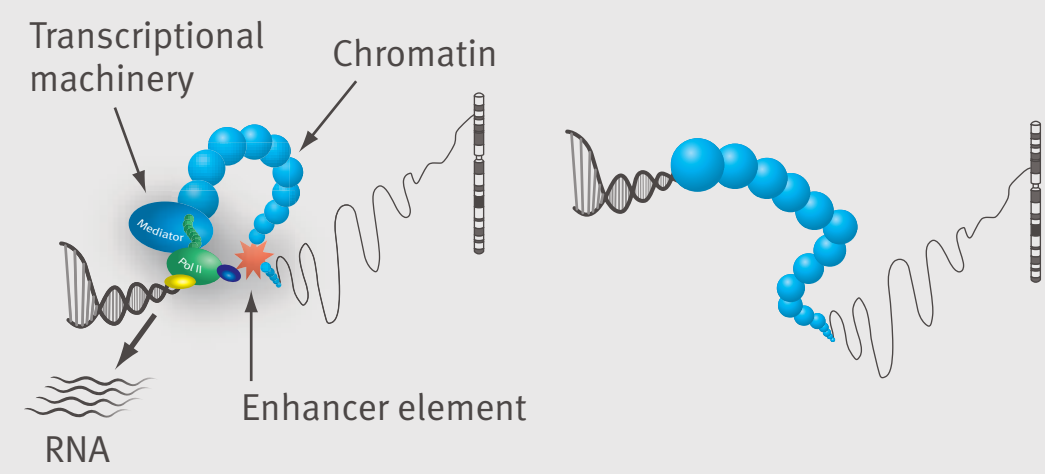

Left: Magical enhancer element within a site of accessible chromatin in human with ancestors all possessing magical abilities (pureblood), which interacts with transcriptional apparatus to drive gene expression. Right: Chromatin in non-magical human (muggle) remains in an inactive closed conformation

\section{Founder effects}

As most magical communities are isolated, high rates of inbreeding and assortative mating (see glossary) are possible, resulting in lower genetic variation for the magical population (that is, a founder effect). ${ }^{14}$ This might be partly why magical ability seems to be passed on from generation to generation without fail in matings between humans with magical abilities. The exception to this would be offspring who are squibs. The heritability of the squib phenotype is unknown as no matings between squibs have been described. Matings between muggles and magical folk always seem to result in offspring with magical abilities, suggesting that a dominant gene is at play. The relative frequency of offspring with magical abilities in matings between muggles argues against a simple dominant gene effect. This could be explained, however, if muggles with magical abilities are those descended from squibs in previous generations who have integrated into muggle society.

\section{DISCUSSION}

The observed inheritance of magic in the Harry Potter books by J K Rowling would be best explained by a multilocus model with a dominant gene for magic, the function of which is controlled epistatically by one or more other loci, ${ }^{15}$ possibly recessive in nature. The genotypes of the loci concerned influence total magical ability, and the allele frequencies of these magical loci would differ significantly between populations with magical abilities and those without (muggles). We cannot yet confirm this finding, however, as those with magical backgrounds have not been included in the International HapMap project. ${ }^{16}$ Genetic heterogeneity may exist.

\section{Magical enhancers and candidate genes}

We hypothesise that a profound mutation in an evolutionary ancestor occurred in a histone gene, which radically altered genome wide chromatin structure. This created new sites of chromatin accessibility and altered gene regulation, including novel enhancer elements to drive "magical" type expression of genes (figure). Such magical enhancers would join a growing list of regulatory elements such as promoters, enhancers, silencers, insulators, and locus control regions. ${ }^{17}$ These regulatory elements are currently being identified and catalogued by the Encyclopedia of DNA Elements (ENCODE) Project Consortium, with analysis of $1 \%$ of the human genome recently reported..$^{18} \mathrm{~A}$ dominant mutation in the histone gene could provide heritability of this epigenetic effect. ${ }^{19}$ Such a mechanism originating in our ancestors would account for non-human magical creatures with some magical abilities (for example, house elves, goblins, centaurs). The basic human genetic structure still develops, making wizards and witches in most ways phenotypically similar to muggles. Squibs may result from an as yet unidentified compensatory epigenetic phenomenon, which returns the chromatin to near normal (muggle) function.

If DNA sequence variants arise on this background then the capacity for magical expression of genes may differ between wizards. For example, given the reported 


\section{WHAT IS ALREADY KNOWN ON THIS TOPIC}

Magical abilities may be heritable

Complete family lineages to study this topic have only recently become available

\section{WHAT THIS STUDY ADDS}

Some aspects of magical ability have a genetic basis

This is not a simple single gene effect and may be related to "magical enhancer" elements

association between genes and speech and language, further mutations at the FOXP2 gene ${ }^{20}$ could account for the rare magical ability to speak to snakes (parseltongue), whereas variants at the MC1R gene may explain Nymphadora Tonks's ability to change her hair colour. The MC1R gene encodes the melanocortin-1 receptor, which is involved in regulation of pigmentation. ${ }^{21}$ This gene is known to be highly polymorphic and variants have been associated with differences in hair colour. ${ }^{21}$ NF2 is another candidate gene for magic. NF2 encodes Merlin, the moesin ezrin radixin related protein, and mutations within this gene could lead to magical effects consistent with the known role of Merlin in coordinating multiple cellular signalling events. ${ }^{22}$ However, anything acting upstream of Hippo and Warts kinases would not, we feel, meet with the approval of such magical luminaries as Albus Dumbledore, the headmaster of Hogwarts school.

Without population based studies to confirm our points these findings should be treated with caution, but using the information available we can be certain that some aspects of magical ability are heritable. We await with bated breath the results of a genome wide association study for magic.

We thank the three underage witches who gave specialist advice on more technical aspects of the Harry Potter novels and David Dyment, Blanca Herrera, Emma Walton, and Claire Vandiedonck for helpful comments.

Contributors: JCK and MK conceived the study. JCK designed the study and is the guarantor. All authors analysed and interpreted the data and wrote the paper.

Funding: SVR is funded by the Medical Research Council of the United Kingdom. MK is funded by a postdoctoral award from the Department of Health National Coordinating Centre for Research Capacity Development. GCE is the action research professor of clinical neurology at the University of Oxford. ICK is a Wellcome Trust senior research fellow in clinical science. The National Perinatal Epidemiology Unit is funded by the Department of Health in England. The views expressed in this paper are those of the authors and do not necessarily reflect the views of the Department of Health.

Competing interests: None declared.

Ethical approval: Not required.

Provenance and peer review: Not commissioned; externally peer reviewed.

1 Weedon MN, Lettre G, Freathy RM, Lindgren CM, Voight BF, Perry JR, et al. A common variant of HMGA2 is associated with adult and childhood height in the general population. Nat Genet 2007:39:1245-50.

2 Frayling TM, Timpson NJ, Weedon MN, Zeggini E, Freathy RM, Lindgren $\mathrm{CM}$, et al. A common variant in the FTO gene is associated with body mass index and predisposes to childhood and adult obesity. Science 2007;316:889-94.

3 Craig JM, Dow R, Aitken M. Harry Potter and the recessive allele. Nature 2005;436:776

4 Dodd A, Hotta C, Gardner M. Harry Potter and the prisoner of presumption. Nature 2005;437:318.

5 Rowling JK. Harry Potter and the deathly hallows. London: Bloomsbury, 2007.
6 Rowling JK. Harry Potter and the philosopher's stone. London: Bloomsbury, 1997.

7 Rowling JK. Harry Potter and the chamber of secrets. London: Bloomsbury, 1998

8 Rowling JK. Harry Potter and the prisoner of Azkaban. London: Bloomsbury, 1999.

9 Rowling JK. Harry Potter and the goblet of fire. London: Bloomsbury, 2000.

10 Rowling JK. Harry Potter and the order of the phoenix. London: Bloomsbury, 2003.

11 Rowling JK. Harry Potter and the half-blood prince. London: Bloomsbury, 2005

12 Risch N. The genetic epidemiology of cancer: interpreting family and twin studies and their implications for molecular genetic approaches. Cancer Epidemiol Biomarkers Prev 2001;10:733-41.

13 Falconer DS. Introduction to quantitative genetics. 3rd ed. Harlow: Longman Scientific and Technical, 1989.

14 Peltonen L, Palotie A, Lange K. Use of population isolates for mapping complex traits. Nat Rev Genet 2000;1:182-90.

15 Carlborg 0, Haley CS. Epistasis: too often neglected in complex trait studies? Nat Rev Genet 2004; 5:618-25.

16 Consortium $\mathrm{TIH}$. The international HapMap project. Nature 2003;426:789-96.

17 Felsenfeld G, Groudine M. Controlling the double helix. Nature 2003;421:448-53.

18 Birney E, Stamatoyannopoulos JA, Dutta A, Guigo R, Gingeras TR, Margulies EH, et al. Identification and analysis of functional elements in $1 \%$ of the human genome by the ENCODE pilot project. Nature 2007;447:799-816.

19 Kadota M, Yang HH, Hu N, Wang C, Hu Y, Taylor PR, et al. Allele-specific chromatin immunoprecipitation studies show genetic influence on chromatin state in human genome. PLoS Genet 2007;3:e81.

20 Vernes SC, Nicod J, Elahi FM, Coventry JA, Kenny N, Coupe AM, et al. Functional genetic analysis of mutations implicated in a human speech and language disorder. Hum Mol Genet 2006;15:3154-67.

21 Beaumont KA, Shekar SL, Newton RA, James MR, Stow JL, Duffy $\mathrm{DL}$, et al. Receptor function, dominant negative activity and phenotype correlations for MC1R variant alleles. Hum Mol Genet 2007;16:2249-60.

22 Curto M, McClatchey Al. Nf2/Merlin: a coordinator of receptor signalling and intercellular contact. BrJ Cancer 2007: doi 10.1038/ sj.bjc.6604002.

\section{GLOSSARY}

Assortative mating-people tending to mate with others like themselves

Chromatin-complex of DNA and protein that constitute chromosomes

Epigenetics-heritable changes in gene function not involving changes in DNA sequence

Epistasis-action of one gene modified by another Founder effect-increase in gene frequency when a population has only a small number of original settlers (founders), one or more of whom had that gene HapMap project-haplotype (series of correlated alleles) map of the human genome, currently being analysed in populations of African, Asian, and European ancestry

Histones-main protein components of chromatin House elves-human-like creatures with distinctive magical abilities who are bound to, and act as servants for, several magical families

Metamorphmagus-someone with the ability to change their physical appearance

Muggle-someone with no magical abilities

Parseltongue-ability to talk to snakes

Pureblood-someone whose ancestors all possess magical abilities

Seer-someone who can predict the future

Squib-someone with virtually no magical abilities who comes from a magical family 


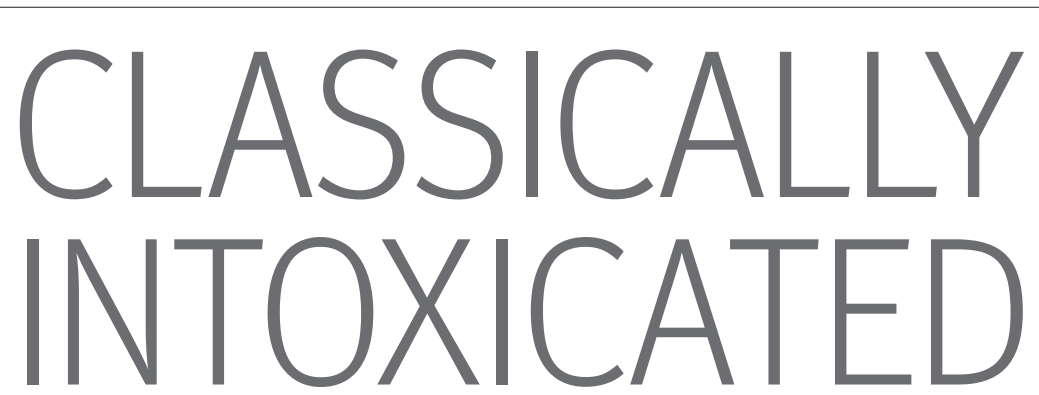

\section{From fragments of a play, Christopher Cook, Helen Tarbet, and David Ball discover that you couldn't teach the ancient Greeks much about drunkenness}

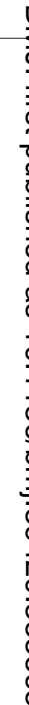

Contemporary discourse about the misuse of alcohol asserts that wise people use alcohol respectfully, appropriately, and moderately whereas unwise people cause harm by inappropriate and immoderate consumption. This is implicit in the foreword to the UK government's Alcohol Harm Reduction Strategy for England written by the then prime minister Tony Blair. ${ }^{1}$ We consider a classical text in which an early form of this message about drinking may be identified.

\section{Drinking in classical Greek society}

Drinking in classical Greek society (about the 5 th and 4 th centuries BC) took place in various contexts. ${ }^{2}$ The symposium provided men in the higher echelons of society with a formal social context for drinking. After dinner, groups of between about 14 and 22 men, but sometimes as many as 30 , reclined on couches around a room to engage in drinking, conversation, and song. A cup of wine was initially passed around as a libation to the divinity, but subsequently the wine was diluted with $50 \%$ to $75 \%$ water, ${ }^{3}{ }^{4}$ mixed in a large bowl or krater.
A slave ladled the diluted wine into a jug and then poured the wine into the guests' cups; alternatively, a cup of the diluted wine was passed around. Guests were expected to consume equal amounts of wine during the evening, the amount being determined both by discussion beforehand and by the pace set by the symposiarch as the evening progressed. Three kraters seem to have been deemed a reasonable quantity for the evening. Moderate drinking was understood as facilitating conversation, which was supposed to predominate over drinking, but that is not to say that drinking did not take pre-eminence sometimes.

For the lower echelons of society wine was sold in the tavern in larger quantities for consumption at home, or else in smaller and diluted quantities for consumption on the premises. Drinking in the tavern was not in the ordered manner of the symposium.

\section{Fragments of a comic play}

The relation between alcohol consumption and alcohol related problems is described in a play attributed to Eubulus, a Greek comic poet of the 4 th century BC. The play is not necessarily to be taken seriously but it does betray the assumptions and world views of the society in which it was written.

The title of this play is traditionally given as Semele or Dionysus. According to Greek mythology, Semele was the human mother of Dionysus, the Greek god of wine (his father was Zeus). Dionysus (in Roman mythology known as Bacchus) was a more complex and subtle character than the commonly held view suggests. Dionysian ecstasy was not merely drunkenness but a state of divine possession, in which humans might behave in an emotional and uncharacteristic way; in the worst imaginable scenario committing violent acts (as in the tragic play The Bacchae, by Euripides). However, little is known about what happened at Dionysiac rites.

Three fragments of the play survive (box)..$^{5}$ Evidence is lacking for a krater being a standard measure equivalent to the contemporary notion of a "unit" of alcohol. Inspection of the kraters on display in the British Museum in London suggests that

Effects of successive kraters of wine

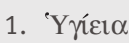

(Hygeia/health)

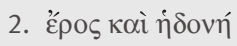

3. $\tilde{\pi} \operatorname{vos}$

4. ข̌ßpts

5. ßoп́

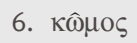

7. $\dot{\pi} \omega \dot{\pi} \iota \alpha$

8. $\kappa \lambda \eta \tau \eta ́ \rho ~$

9. $\chi 0 \lambda \eta ́$

10. $\mu \alpha v i \alpha$ (love and pleasure)

(sleep)

(hubris)

(shouting)

(drunken revels)

(black eyes)

(witness)

(anger)

(mania) 
they were variably sized but potentially quite large-more like a fruit bowl than a wine glass-and that they were shared among a variable number of guests. None the less, the description of the effects of between one and 10 kraters of wine suggests a recognition of the progressive effects of alcohol on humans, proportionate to the amount consumed.

\section{Classical understanding}

The effects of each successive krater of wine are portrayed in the text by nouns used in the genitive form. The first four nouns, associated with the first three kraters, are unambiguously positive (box).

Traditionally three toasts were drunk before a symposium, with the third toast usually being drunk to Hygeia, the goddess of health. It is not clear why Hygeia comes first in the text, but the Greek is ambiguous and can equally be taken to imply that the first krater belongs simply to "health" rather than to Hygeia. In any case this text refers to the appropriate number of kraters to be consumed during a symposium and not to the preceding toasts.

After the first three kraters, Dionysus suggests that the one who is wise will go home. The implied threshold is therefore three kraters of diluted wine, below which drinking is enjoyable and healthy and above which it is unwise to proceed. The effects of subsequent kraters of wine are all negative (box).

It might be possible to infer a progression, from relatively minor adverse consequences of hubris and shouting through to being both the victim and the perpetrator of violence who is taken to court, through to eventual madness or possession. In this text, however, Dionysus has disclaimed responsibility for this "possession." It was his advice that the drinker should go home after only three kraters of wine. Furthermore, in

\section{The three fragments of the play}

The fragment known as Fragment 93 describes the successive consumption of between one and 10 kraters of diluted wine. Dionysus speaks, apparently in the role of symposiarch: "I mix three kraters only for those who are wise. One is for good health, which they drink first.

The second is for love and pleasure.

The third is for sleep, and when they have drunk it those who are wise wander homewards.

The fourth is no longer ours, but belongs to arrogance.

The fifth leads to shouting.

The sixth to a drunken revel.

The seventh to black eyes.

The eighth to a summons.

The ninth to bile.

The tenth to madness, in that it makes people throw things."

fourth century Greek law, hubris was a civic offence that covered physical assault and perhaps also rape and adultery, as well as a host of more minor offences. According to Aristotle, men were thought to have committed hubris not because of an innocent excess of high spirits or a desire to redress some balance but because they wanted to take pleasure from degrading another person. The more serious offences were liable to severe penalties imposed by courts. It is therefore possible that the successive effects of the fifth through to the 10th kraters of wine are all to be understood as the results of hubris.

Although the description of the effects of these additional kraters of wine is unambiguously negative, there is still room to see a possible division of opinion within classical Greek society that mirrors the division of opinion in contemporary Western society. The "drunken revels," associated with the sixth krater, relate to the end of the evening, when the party leaves the symposium and spills out on to the streets. This part of the evening was often the occasion for acts of vandalism and violence (hence the reference to black eyes and the inference of a possible court appearance) but the evening could also pass off relatively peacefully-apart from waking the neighbours! It carried a sense of enjoyable revelry as well as of being an antisocial vice, just as contemporary youth culture might see getting drunk as a good way to spend a Saturday evening out, despite the disapproval of wider society.

The black eyes (or literally "under the eyes") associated with the seventh krater might be understood as descriptive of the baggy eyes of someone who has a hangover, or else of the black eyes of a victim of assault. The effects of the eighth krater are described in terms of being a witness-a legal term that implies involvement in a lawsuit. The association of the next krater with anger employs a word that usually refers to excessive anger, or anger experienced in a physical sense (as "bile"). This sequence thus carries an implication of involvement in court proceedings as a result of violence and of the risk of being both the victim and the perpetrator of violence.

The "mania" attributable to the final (10th) krater is said to cause the drinker to throw, but no object is specified. In some translations www.physics.uq.edu.au/people/nieminen/alcliterature.html\#dionysos and www.winterscapes.com/sannion/wine. htm the throwing of furniture is specified, although the basis for such an inference is not clear. One study ${ }^{6}$ refers to the traditional understanding that madness was associated with the throwing of stones. Possibly an association or similarity was implied between drunkenness and madness. The author notes that the "black bile"

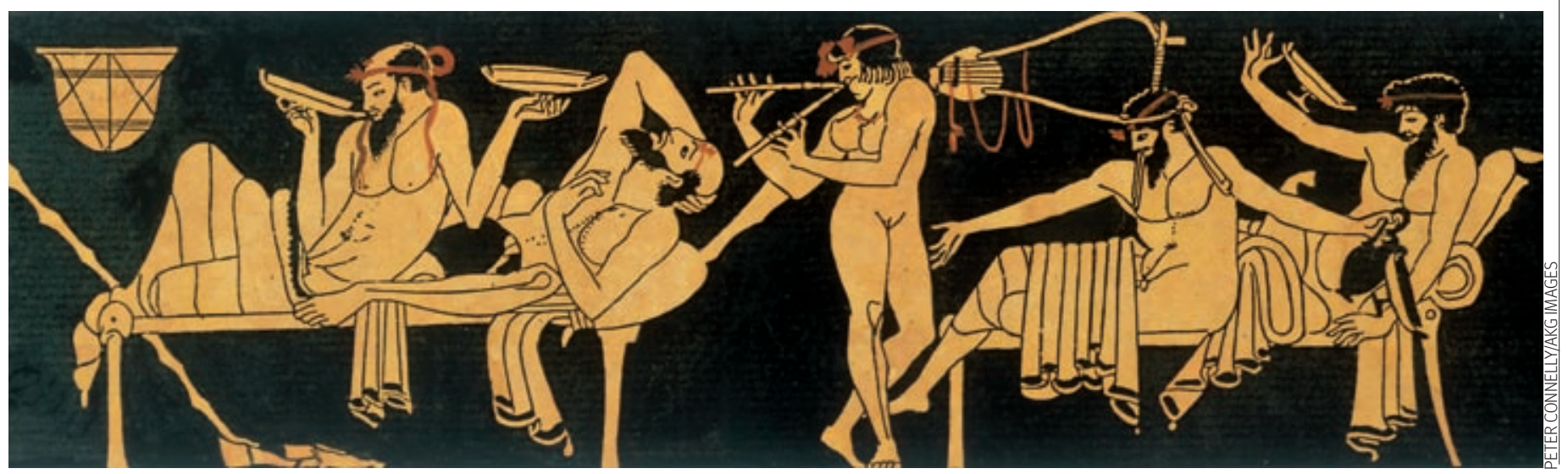


or anger, attributed to the immediately preceding (ninth) krater of wine, was thought to cause madness.

In the final lines of the fragment of the text we are told that, much wine having been poured into one "small vessel," the drinkers will find their legs "pulled from under them." The reference to a small vessel is ambiguous. It might refer to the one krater filled 10 times over but it might also refer to the drinker as a metaphorical vessel. Similarly, the reference to the legs of the drinkers being pulled from under them (the word being that used in wrestling) has a possible double sense of both a literal and metaphorical inability to stand any longer.

\section{Alcohol misuse-ancient and modern}

The idea that alcohol may be used or misused is an ancient one, as are the observations that the effects of alcohol vary according to the amount consumed and that more harmful and undesirable effects are more likely to appear the greater the amount consumed. This understanding would seem to correlate well with everyday observation and asserts the primacy of reason and will over personal behaviour. It suggests that our decisions about our drinking behaviour are what determines observable alcohol related harm.

Contemporary research might well be said, to an extent, to support this distinction between alcohol use and misuse. It is inter-

\section{SUMMARY POINTS}

The nature, severity, and risk of alcohol related problems are correlated with the amount of alcohol consumed by an individual

The classical world was aware of this relation, as is contemporary society

This relation is the basis of the "sensible drinking" message

It therefore appeared in antiquity, as it does today, that the wise person will use alcohol moderately and appropriately

Despite this, educational measures designed to promote sensible drinking are not based on evidence

esting to note, however, that educational measures designed to reinforce moderate or "sensible" drinking actually have little, if any, observable effect in terms of reduced alcohol related harm. ${ }^{7}$ Perhaps the wisdom of classical civilisation, appealing to our desire to understand ourselves as being in control of our own destiny, seems more attractive to us as a basis for alcohol policy than the findings of empirical research?

Christopher $\mathrm{CH}$ Cook is a professorial research fellow at the Department of Theology and Religion, Durham University, Durham DH1 3RS

c.c.h.cook@durham.ac.uk

Helen Tarbet is a postgraduate fellow at the Department of Classics and Ancient History, Durham University

David Ball is a senior lecturer at the Institute of Psychiatry, King's College London
We thank Diana Barclay and lan McEwen for their helpful comments and lan McEwen for his translation of the Greek text.

\section{Competing interests: None declared.}

Contributors and sources: $\mathrm{CCHC}$ has worked for over 20 years in the addictions field, mainly with a clinical and research interest in alcohol misuse. He is particularly interested in spirituality and addiction and has traced the ethical and theological understandings of alcohol misuse in the Christian tradition from their origins in early Jewish and Greco-Roman society. He undertook the major role in drafting and redrafting the paper. HT was, until recently, a postgraduate student in classics at Durham University. She provided classical scholarly input to the writing of the paper and alerted us to the existence of Davidson's useful book. DB is a senior lecturer and honorary consultant psychiatrist with an interest in alcohol misuse, and has undertaken research into the genetic basis of alcohol related problems. The original idea of writing this paper was his. CCHC and DB are guarantors of this paper.

Provenance and peer review: Not commissioned; externally peer reviewed

1 Prime Minister's Strategy Unit. Alcohol harm reduction strategy for England. London: Strategy Unit, 2004.

2 Davidson I. Courtesans and fishcakes: the consuming passions of classical Athens. London: Harper Collins, 1997.

3 Hunter RL. Eubulus: the fragments. Cambridge: Cambridge University Press, 1983:186.

4 Rolleston JD. Alcoholism in classical antiquity. $\mathrm{Br}$ J Inebriety 1927:24:101-20.

5 Kassel R, Austin C, eds. Poetae comici graeci. v 5. Berlin: Walter de Gruyter, 1986.

6 Hunter RL. Eubulus: the fragments. Cambridge: Cambridge University Press, 1983:189.

7 Babor T, Caetano R, Casswell S, Edwards G, Giesbrecht N, Graham K, et al. Alcohol: no ordinary commodity. Oxford: Oxford University Press, 2003:189-207.

\section{A day in the life of a doctor: the computer}

The main purpose of a computer is domination. A computer ensures you do not waste your time seeing patients-or waste your time on other unimportant pursuits such as eating, drinking, sleeping, or making babies.

A subsidiary purpose of a computer is to provide a mini-mental test of your capacity to remember passwords. Passwords on a computer are different for every program, and change as frequently as you change your underwear. Passwords are the name of your deceased dog, or your partner's name spelt backwards, followed by a number that increases exponentially. If you are able to remember all your passwords, you have Asperger's syndrome and should see a doctor immediately. Normal human beings keep their passwords safely hidden on a piece of scrap paper, never to be found again.

Theoretically, computers save trees, except that everyone prints out their electronic documents to read offline, thereby avoiding terminal migraine.

A desktop computer is like a dominatrix. It has everything you want and more, but is determined to demonstrate your inadequacy and your total dependence. The computer knows your patients' laboratory results, so you need never see your patients again. An endless torrent of emails will keep you hostage for hours. Your colleagues are under the delusion that their emails have direct access to your brain, and telephone grumpily if you do not reply within seconds. The emails you do open invariably impugn the size or function of a man's private parts or offer breast enlargement. The computer is programmed to send an email every time you attempt to leave the office, the number of attachments directly proportional to the urgency of the appointment you are missing.

Modern life is about portability and practicality, as you negotiate the declining distinction between work and home life. Mobility is the order of the day-mobile phones, mobile homes, and mobile morals. The solution is a laptop computer. A laptop is like a lapdog but with a brain. It requires a licence and regular nourishment, but will then act as a CAD (conversation avoidance device). A laptop is part of the dress code for all government employees you're likely to encounter and is an essential accessory for aeroplane travel. You will, however, need the coordination of an Olympic gymnast to work the mouse, and the patience of Job when the battery runs out halfway through your flight and loses all your work.

David Isaacs senior staff specialist, Department of Immunology and Infectious Diseases, Children's Hospital at Westmead, Sydney, Australia davidi@chw.edu.au Stephen Isaacs consultant, Waltham Forest Child and Family Consultation Service, London Dominic Fitzgerald senior staff specialist, Department of Respiratory Medicine, Children's Hospital at Westmead 


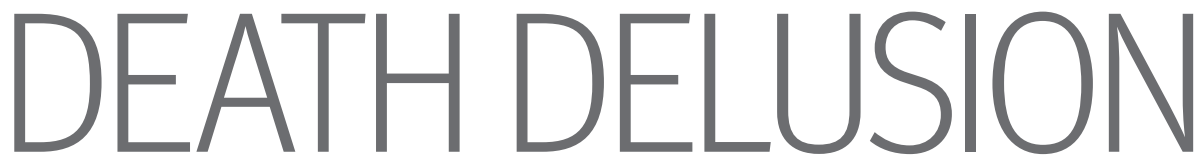

Anders Helldén and colleagues report two cases of Cotard's syndrome as an adverse drug reaction to aciclovir and its prodrug valaciclovir

\section{CASE 1}

A 35 year old woman with a failing kidney transplant was being treated with chronic haemodialysis, prednisolone ( $5 \mathrm{mg}$ daily), and ciclosporin ( $50 \mathrm{mg}$ daily) when she developed herpes zoster. Valaciclovir was prescribed, $1 \mathrm{~g}$ daily, according to standard Swedish recommendations for renal failure at the time. She took the first dose after dialysis on day one and became restless two nights later. On day three she was tired, her body felt unfamiliar, and she felt shut off from the surrounding world. That night, after a total valaciclovir dose of $3 \mathrm{~g}$, she developed anxiety and visual and auditory hallucinations. When she came to the dialysis unit in the morning she could barely walk, cried out, and appeared terrified. Her mother reported that this had been present for several hours. After 45 minutes of haemodialysis her condition improved, she no longer cried out and could speak. After an hour of dialysis she explained that she had been convinced she was dead; now she was not quite so sure. After two hours

she was calm and half asleep but could answer questions and said her arm seemed unfamiliar when she touched it. After three hours she could hold a short conversation but was still tired. After dialysis, she remained ataxic, had difficulty walking and told us how utterly frightening her sense of being dead had been. Valaciclovir was discontinued and she was admitted overnight. Next day she exhibited no further neuropsychiatric symptoms.

We found no cause to account for her sense of being dead other than the treatment with valaciclovir. Thirty hours after the last dose her serum concentration of aciclovir before dialysis was high, at $19.4 \mu \mathrm{mol} / \mathrm{l}$ (close to the peak concentration

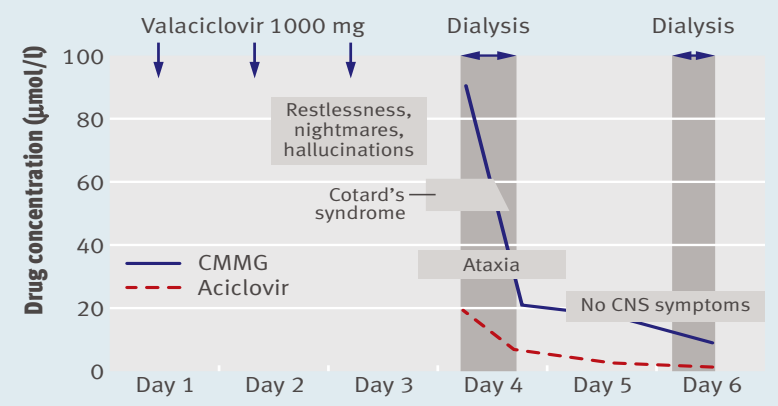

of computed tomography of the brain were normal. Herpes encephalitis was suspected, and on day eight valaciclovir was replaced with intravenous aciclovir $500 \mathrm{mg}$ daily.

On day nine he awoke with fear, anxiety, and slurred speech; he was screaming and asking if he was dead. Intravenous diazepam resolved the symptoms only temporarily. Aciclovir was withdrawn because results of virus isolation and polymerase chain reaction in the cerebrospinal fluid were negative. The feeling of being dead reappeared the one to two hours after a single dose). The serum concentration of the main metabolite, 9-carboxymethoxymethylguanine (CMMG) was also high at 90.2 $\mu \mathrm{mol} / \mathrm{l}$ and decreased during dialysis to $21.1 \mu \mathrm{mol} / \mathrm{l}$, which is still considered high (figure). On day six her serum aciclovir concentration was $1.8 \mu \mathrm{mol} / \mathrm{l}$ and serum concentrations of CMMG were $8.9 \mu \mathrm{mol} / \mathrm{l}$ before dialysis and $1.5 \mu \mathrm{mol} / \mathrm{l}$ after dialysis.

Serum concentrations of aciclovir and CMMG in relation to neuropsychiatric symptoms and Cotard's syndrome in case 1 (to convert values for aciclovir concentration to $\mu \mathrm{g} / \mathrm{ml}$, divide by 4.44; to convert values for CMMG concentrations to $\mu \mathrm{g} / \mathrm{ml}$, divide by 4.18).

following night and he felt depressed and tired the day after. However, his confusion had subsided and his speech improved. During the next night he again believed that he was dead and considered that everybody around him was dangerous. His mental state and renal function finally returned to baseline on day 12. A blood sample 16 hours after the final dose on day nine contained 39 $\mu \mathrm{mol} / \mathrm{l}$ of aciclovir and $29 \mu \mathrm{mol} /$ I of CMMG. On day eight aciclovir and $C M M G$ concentrations in the CSF were $27.5 \mu \mathrm{mol} / \mathrm{l}$ and $3.2 \mu \mathrm{mol} / \mathrm{l}$, respectively.
Jules Cotard first described his eponymous syndrome, a rare psychiatric condition with strong delusions of being dead, in the 1880s. Aciclovir or valaciclovir may cause neuropsychiatric side effects such as confusion, somnolence, and hallucinations, mainly in patients with impaired renal function. ${ }^{1}$ We have not seen the condition ${ }^{2}$ reported as a suspected adverse drug reaction.

In the first patient haemodialysis resulted in rapid improvement; Cotard's syndrome subsided and was followed by a hemineglect syndrome, similar to the alien hand syndrome. 3 The serum concentrations of aciclovir and CMMG decreased substantially, though the CMMG level was still high. We have previously found concentrations $>10 \mu \mathrm{mol} / \mathrm{l}$ to be associated with neuropsychiatric symptoms. ${ }^{2}$ The second patient also had Cotard's syndrome at high aciclovir and CMMG concentrations and experienced slow recovery over three days as the serum concentration declined. Both patients were treated with reduced doses based on their renal impairment, as recommended at that time. Neither of them had any evidence of liver dysfunction.

Cotard's syndrome has been associated with severe somatic stress as well as general and localised cerebral pathologies. ${ }^{4}$ Our findings add adverse response to an antiviral drug as another cause and provide clues to the syndrome's possible neuropsychiatric origin. Clinicians should be aware of the association between body scheme disturbances and (val)aciclovir. Affected patients with Cotard's syndrome and renal failure should preferably be sent to the dialysis unit, not to the department of psychiatry.

Contributors and sources: $\mathrm{AH}$ is working on his $\mathrm{PhD}$ thesis on aciclovir induced adverse drug reactions. IOC and IF were responsible for the first patient, and IOC diagnosed the valaciclovir adverse drug reaction. KL was responsible for the second patient. AH, IOC, and TL wrote the article. All have drafted the manuscript and provided final approval. This article arose from a conversation between AH and TL, TL immediately diagnosing Cotard's syndrome from the symptoms that AH reported. AH is guarantor.

Anders Helldén (anders.hellden@ki.se), Ingegerd OdarCederlöf and Kajsa Larsson are at the Karolinska University Hospital, Stockholm. Ingela Fehrman-Ekholm is at Queen Sophia's Hospital, Stockholm Thomas Lindén is at Gothenburg University.

Competing interests: $\mathrm{AH}$ has received an unrestricted grant from GlaxoSmithKline for a pharmacokinetic study. Provenance and peer review: Not commissioned; externally peer reviewed.

1 Helldén A, Odar-Cederlöf I, Diener P, Barkholt L, Medin C, Svensson JO, et al. High serum concentrations of the acyclovir main metabolite 9-carboxymethoxymethylguanine in renal failure patients with acyclovir-related neuropsychiatric side effects: an observational study. Nephrol Dial Transplant 2003;18:1135-41.

2 Cotard J. Du délire des négations. Arch Neurol 1882;4:152-170, 282-96.

3 Scepkowski LA, Cronin-Golomb A. The alien hand: cases, categorizations, and anatomical correlates. Behav Cogn NeurosciRev 2003;2:261-77.

4 Berrios GE, Luque R. Cotard's syndrome: analysis of 100 cases. Acta Psychiatr Scand 1995;91:185-8. month earlier). The next day

he was confused but results 


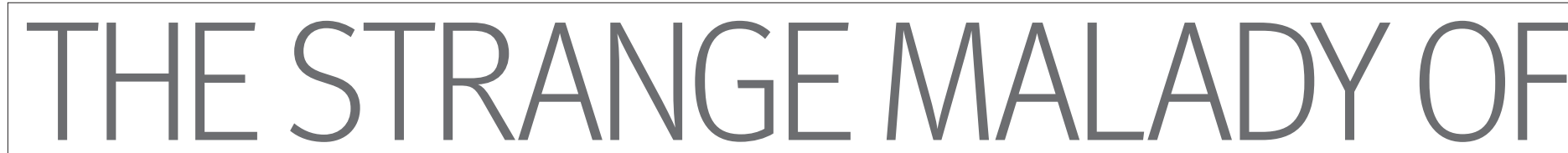

Shortly before Alessandro covered the scientific meeting as a reporter for L'Unione Sarda, he had learnt that his uncle was being treated for the disorder that the professor was speaking about. At the end of the session, Alessandro picked up the press release in the congress media room.

It read: "Under the leadership of Professor Henry Johnson, a team of scientists from universities in Europe and the United States announced the discovery of a major gene for schizophrenia at the Fifteenth International Congress of Genetic Psychiatry in Cagliari, Sardinia, today. They studied the genes from an international collection of patients with schizophrenia, their normal parents, and their siblings. Patients with schizophrenia were five times more likely to possess a genetic variant (allele) of a gene than their unaffected relatives. The scientists have named this gene Schizo-12. Professor Johnson said that a test to detect the presence of the variant would be on the market within a year, and a drug that would prevent or effectively treat schizophrenia in patients who tested positive would be developed within five years. The work was supported by Psychotropics-R-Us, an American drug company."

A month before the congress, Alessandro had driven to the mountainous region of Barbagia, northeast of Cagliari, to visit his uncle who was a goatherd. After he had parked on the side of a dirt road, he hiked the mile to his uncle's stone hut, arriving at midday. He found his uncle seated on a stool on one side of a rough hewn table. On each of the other three sides a goat sipped milk from its bowl, forefeet firmly planted on the table, hind legs on the earthen floor. While he waited for his uncle to finish eating, Alessandro inspected the hut. $\mathrm{He}$ noticed a crumpled paper on the otherwise empty shelf above his uncle's cot. He took it to the table where he smoothed it out. "Who gave this to you?" he asked his uncle.

"A doctor."
A tale of overhyped genetic discovery by Neil A (Tony) Holtzman

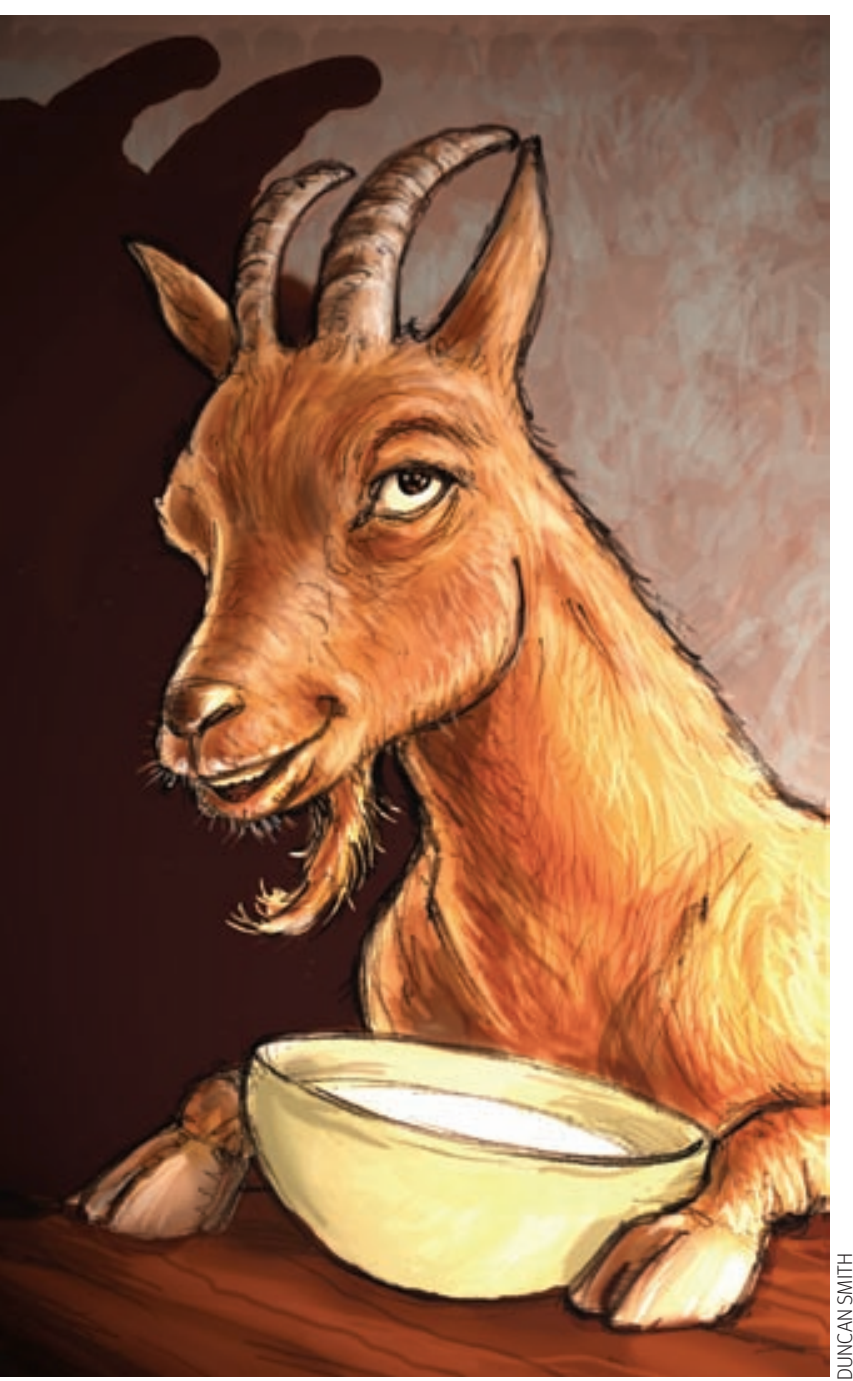

sequence of events that had led to the diagnosis.

The previous spring-after the winter snows had melted off the Gennargentu-a public health nurse from Cagliari was making her calls through the Barbagia. She arrived by foot at the goatherd's hut, knocked, and entered when he grumbled, "Avanti." After her eyes became accustomed to the darkness she saw three of his goats standing around the table, exactly as Alessandro saw several months later. Sitting on a stool, the goatherd occupied the fourth side, his elbows on the table, watching the goats as they sipped their milk. Occasionally, the old man uttered a few words. The nurse thought he was speaking gibberish.

In early autumn, the nurse returned with the doctor while the goatherd was having lunch. After introducing the doctor, the nurse urged the goatherd to continue his meal as she and the doctor retreated to the shadows in the one room hut. The doctor thought the goatherd was speaking logudorese (an ancient Sardinian dialect) to his four legged companions. Stepping from the shadows, the doctor asked the old man a few questions, had him stick out his tongue, and then wrote the prescription, which Alessandro found on his visit a few weeks later.

After Alessandro read the press release, he wanted to question Pro-

"Were you sick?" His uncle shook his head. "What were you doing when the doctor came?"

"Having lunch."

"Was anyone else here?"

"A nurse-and my pet goats."

Alessandro took the prescription back to Cagliari. He did a Google search on olanzapine, the prescribed drug, and learnt that the drug was used to treat schizophrenia.

Surprised, Alessandro made an appointment to see the doctor who had signed the prescription. The doctor confirmed that his uncle had schizophrenia. After more inquiries, Alessandro pieced together the fessor Johnson about his uncle-did the professor think he had schizophrenia? Could he get the Schizo-12 test and what was the best treatment? But the professor was nowhere to be seen. Alessandro returned to the offices of L'Unione Sarda in Cagliari, where he wrote his story. It appeared in the next printed edition and on the paper's website. The story was quickly picked up by Corriere della Sera, which published an English translation.

The next morning, congress participants were surprised by the newspaper headlines. The International Herald Tribune proclaimed, "Gene for schizophrenia found." Other papers bore similar captions. By email, a few of the 


\section{ALESSANDRO'S UNCLE}

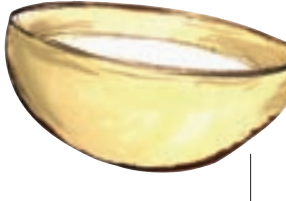

participants from the United States ordered their stockbrokers to buy shares in Psychotropics-R-Us. The time was then only 3 am in New York.

A few hours later the story was on US National Public Radio's weekday morning news show. ABC television had awakened a well known American psychiatrist and brought him to the nearest studio where his comments on the report were viewed by millions on Good Morning, America. "If the results are confirmed," he said, "the findings are very exciting."

Psychotropics-R-Us stock opened on the New York stock exchange that morning at \$4 a share. It closed at $\$ 26$.

The president of the congress and Henry Johnson were deluged with phone calls and email messages. The president decided to convene a special public session the next day at which Johnson would summarise the findings and then invite questions. One of Johnson's English collaborators and the scientific director of Psychotropics-R-Us flew to Cagliari to participate in the session.

Unlike the previous sessions, the special one was packed. Johnson summarised his group's findings and concluded with the prediction that a test for Schizo-12 would be available within a year and a treatment within five years. The first questions concerned the DNA analyses and the association studies. Johnson and his colleagues answered them with ease.

Then, a reporter at the back of the auditorium asked, "You call this gene Schizo-12. Are there 11 others?"

Johnson replied, "Yes there are, but the claims for an association with schizophrenia were not based on as large a number of patients. Some of the claims have been retracted, but the gene names stick."

The reporter then asked, "What was the basis for the retractions?"

Johnson's British colleague answered, "A few relatives who had neither any symptoms of schizophrenia nor the predisposing allele were classified as normal. After the study was published, they were diagnosed with schizophrenia. The same problem has been reported for bipolar affective disorder."

Alessandro asked, "Professor, would you say that a man who heard his pet goats talking had schizophrenia?"

Surprised, Johnson thought for a moment and said, "Well, I'm not a psychiatrist, you know," he paused, gazing at the ceiling, "but keeping goats for pets is unusual to begin with. I would say he probably does."

Alessandro wanted to add that the man in question was a goatherd, but the president called on a woman who had been standing by one of the floor microphones. She asked, "Dr Johnson, do you own stock in Psychotropics-R-Us?"

"Yes, I do."

"Doesn't that pose a conflict of interest?"

"If you are insinuating that I or my colleagues fabricated results I find that highly insulting."

She clung to the microphone and responded before the president pointed to the next person. She replied, "No, professor, I am only suggesting that it is in your financial interest to develop the test and get the drug to the market as soon as possible."

As Johnson hesitated, the president called on the next questioner, a distinguished congress participant from the London School of Hygiene and Tropical Medicine. "Your slides," he began, "showed the frequency of the predisposing Schizo-12 allele to be 10 times higher than the frequency of schizophrenia. Under those conditions, most people who have the allele will never develop schizophrenia."

The scientific director of Psychotropics-RUs shot back, "But they have five times the risk of people without Schizo-12."

Not to be fazed, the distinguished participant replied calmly, "That may be, but if you are going to prescribe drugs for healthy people who test positive for the predisposing allele, most will never benefit from the drug." A murmur went through the audience. "From your data, I might add, this allele will account for less than one third of cases of schizophrenia." ${ }^{2} \mathrm{He}$ turned and walked away from the microphone. Abruptly, the president thanked Johnson, his colleagues, and the audience for their interest, and adjourned the session.

Psychotropics-R-Us shares hovered around $\$ 25$ for the next two years. Then the company offered a test for Schizo-12 in its own laboratory, thereby circumventing the tight control the US Food and Drug Administration (FDA) has over genetic tests sold as kits to other laboratories. ${ }^{3}$ Once the test was on the market, the company's shares rose to $\$ 40$ each.

Several people who were tested for the Schizo-12 variant committed suicide shortly after learning their results were positive.
Some families of people in whom the test was negative sued Psychotropics-R-Us when they were diagnosed with schizophrenia. When the company abandoned its test for Schizo-12, the media did not report it.

Three years after the Sardinia meeting, the FDA refused to allow Psychotropics-R-Us to begin phase III trials of its "anti-Schizo-12" drug because of safety concerns. A report of this denial was buried on the back page of the business section of the major papers. The price fell to $\$ 5$ a share.

Together with an expanded group of collaborators who provided many more patients with schizophrenia and controls, Henry Johnson submitted an abstract to the 17th International Congress of Genetic Psychiatry in Bangkok, Thailand, four years after the Sardinia meeting. They reported that the risk of schizophrenia in people with the Schizo-12 allele was only 1.5 times that of relatives without the allele (95\% confidence intervals 0.8 to 1.9$)$. The abstract was not accepted for presentation. As expected, no newspaper published this non-event.

Alessandro had his uncle's prescription for olanzapine filled and brought the medicine to the goatherd. Whether his uncle or his pet goats took the medicine is unclear, but the pills disappeared. When the nurse returned to the mountains the next spring she found the old man still discussing matters with his pet goats over lunch.

Neil A (Tony) Holtzman is professor emeritus pediatrics at McKusick-Nathans Institute of Genetic Medicine, Johns Hopkins Medical Institutions, Baltimore, MD 21205, USA nholtzma@jhsph.edu

Competing interests: $\mathrm{NAH}$ was reimbursed for attending the symposium at which the paper was presented by the organisers.

Provenance and peer review: Not commissioned; not externally peer reviewed.

A slightly different version of this story was presented by invitation at the Fourteenth World Congress on Psychiatric Genetics, Sardinia, Italy, October, 2006, under the title

"Genetic tests, commercialization, and conflict of interest." Any resemblance to persons living or dead is purely coincidental.

1 Kelsoe JR, Ginns El, Egeland JA, Gerhard DS, Goldstein AM, Bale SJ, et al. Re-evaluation of the linkage relationship between chromosome 11p loci and the gene for bipolar affective disorder in the Old Order Amish. Nature 1989:342:238-43.

2 Holtzman NA, Marteau TM. Will genetics revolutionize medicine? N EnglJ Med 2000;343:141-4.

3 Pollack A. A crystal ball submerged in a test tube; genetic technology reshapes the diagnostics business. New York Times 2006 April 13. http://query.nytimes.com/gst/ fullpage.html?res=9D00EED81F30F930A25757COA960 9 C 8 B $63 \&$ sec $=\&$ spon $=\&$ pagewanted $=$ print 